Magdalena Kalinowska ${ }^{1}$

http://dx.doi.org/10.18778/8088-306.2.12

\title{
Sytuacja prawna pracowników a postępowania restrukturyzacyjne
}

Rewolucja w przepisach dotyczących bankructwa oraz procedur prewencyjnych, dokonana wraz z uchwaleniem ustawy z dnia 15 maja 2015 r. Prawo restrukturyzacyjne (Dz.U. 2015.978)², odbiła się szerokim echem w całym systemie prawa prywatnego doprowadzając do licznych zmian w szeregu innych ustaw, a także w sposób relewantny wpływając na sytuację prawną podmiotów pozostających w związku z dłużnikiem, który ze względu na swoją sytuację finansową został zmuszony do poddania się procedurom restrukturyzacyjnym bądź do ogłoszenia upadłości. Do podmiotów tych zalicza się m.in. pracowników zatrudnionych przez takiego dłużnika. W związku ze skalą wprowadzonej nowelizacji zachodzi potrzeba omówienia nowych regulacji dotyczących pracowników niewypłacalnego albo zagrożonego niewypłacalnością dłużnika.

\section{Geneza oraz ogólna charakterystyka postępowań restrukturyzacyjnych}

Aby możliwe było dokładne zrozumienie tak szczegółowej kwestii, jaką jest wpływ postępowań restrukturyzacyjnych na sytuację prawną pracowników zatrudnionych przez dłużnika, konieczne jest krótkie omówienie ogólnych zagadnień związanych z dokonaną nowelizacją. Przede wszystkim należy zwrócić uwagę na to, że wprowadzone zmiany stanowią próbę dostosowania regulacji związanych z niewypłacalnością dłużnika do zmieniających się warunków gospodarczych, między innymi poprzez skrócenie czasu postępowania, zmniejszenie jego kosztów oraz zwiększenie stopnia zaspokojenia wierzycieli przy jednoczesnym dążeniu do zachowania przedsiębiorstwa dłużnika ${ }^{3}$. Głównym założeniem ustawodawcy było odwrócenie tendencji do składania wniosków o ogłoszenie upadłości obejmującej likwidację

\footnotetext{
1 Doktorantka, Uniwersytet Łódzki, Wydział Prawa i Administracji, Katedra Prawa Gospodarczego i Handlowego.

2 Ustawa z dnia 15 maja 2015 r. Prawo restrukturyzacyjne, której wejście w życie nastąpiło z dniem 1 stycznia 2016 r., Dz.U. z 14 lipca 2015 r., poz. 978, w skrócie PrRestr. 3 Patrz: uzasadnienie do projektu ustawy prawo restrukturyzacyjne dostępne na https://www.ms.gov.pl/pl/nowelizacja-prawa-upadlosciowego-inaprawczego/download,2585,19.html, s. 7.
} 
majątku upadłego. Zdaniem R. Adamusa taki stan rzeczy wynikał z dysfunkcji dotychczasowego układu, które utrudniały jego zawarcie ${ }^{4}$. Stąd wierzyciele niewypłacalnych dłużników chcąc jak najszybciej zaspokoić choć część swoich wierzytelności preferowali postępowanie upadłościowe obejmujące likwidację majątku upadłego, w obawie, że zawarty układ i tak nie zostałby wykonany, a szanse na uzyskanie zapłaty $\mathrm{z}$ upływem czasu stałyby się jeszcze mniejsze.

W celu uatrakcyjnienia procedur restrukturyzacyjnych ustawodawca wprowadził aż cztery rodzaje tych postępowań ${ }^{5}$. Jak stanowi art. 2 PrRestr restrukturyzację przeprowadza się w następujących postępowaniach restrukturyzacyjnych: postępowaniu o zatwierdzenie układu, przyśpieszonym postępowaniu układowym, postępowaniu układowym oraz postępowaniu sanacyjnym. Wspólnym mianownikiem wymienionych postępowań jest zawarcie układu, za pomocą którego następuje reorganizacja zobowiązań dłużnika, która pozwala na uniknięcie ogłoszenia upadłości, a w przypadku postępowania sanacyjnego, także przeprowadzenie działań sanacyjnych (art. 3 ust. 1 PrRestr)6. Istotne jest to, że postępowania restrukturyzacyjne należy prowadzić w taki sposób, aby zapewnić ochronę słusznych praw i interesów wierzycieli, a zatem restrukturyzacja zobowiązań dłużnika może

\footnotetext{
4 Zob. Adamus R., Prawo restrukturyzacyjne. Komentarz, stan prawny na 2015 r., uwagi do art. 1 PrRestr., Legalis - autor jako przykładową dysfunkcję w zawarciu układu wskazuje problem naliczania i dochodzenia odsetek od wierzytelności układowych za okres po ogłoszeniu upadłości z możliwością zawarcia układu.

5 Zob. Adamus R., Prawo restrukturyzacyjne..., uwagi do art. 2 PrRestr., Legalis

${ }^{6}$ Ustawa z dnia 28 lutego 2003 r. Prawo upadłościowe i naprawcze (tekst jedn. Dz.U. 2015.233 z późn zm.) przewidywała jednolitą kategorię postępowania upadłościowego, które mogło występować w dwóch wariantach: jako postepowanie upadłościowe obejmujące likwidację majątku upadłego albo postępowanie upadłościowe z możliwością zawarcia układu. Obecnie mamy do czynienia z powrotem do istniejącego od czasów dwudziestolecia międzywojennego do chwili wejścia w życie ustawy Prawo upadłościowe i naprawcze podziału na postępowania związane z układem oraz postępowanie upadłościowe, w ramach którego dochodzi do likwidacji przedsiębiorstwa dłużnika (zob. rozporządzenie Prezydenta Rzeczypospolitej Polskiej z dnia 24 października 1934 r. Prawo upadłościowe, Dz. U. z 1934 r. Nr 93, poz. 834 z późn. zm. oraz rozporządzenie Prezydenta Rzeczypospolitej Polskiej z 24 października 1934 r. Prawo o postępowaniu układowem, Dz. U z 1934 r. Nr 93, poz. 836 z późn. zm.). Ustawa Prawo restrukturyzacyjne wprowadziła cztery rodzaje postępowań restrukturyzacyjnych zastępując nimi postępowanie upadłościowe z możliwością zawarcia układu oraz doprowadziła do wykreślenia z ustawy Prawo upadłościowe i naprawcze, której obecna nazwa brzmi - Prawo upadłościowe, przepisów dotyczących postępowania upadłościowego z możliwością zawarcia układu oraz postępowania naprawczego, jak również do szeregu innych zmian mających na celu zharmonizowanie przepisów obydwu ustaw.
} 
nastąpić tylko za zgodą odpowiedniej liczby wierzycieli7. Jednakże, jeśli chodzi o kwestię samego wniosku restrukturyzacyjnego, uprawnionym do jego złożenia jest dłużnik. Zgodnie bowiem z treścią art. 7 PrRestr o ile ustawa nie stanowi inaczej, postępowanie restrukturyzacyjne wszczyna się na wniosek złożony przez dłużnika. Wyjątek od tej zasady znajdziemy w art. 283 ust. 2 PrRestr, który uprawnia do złożenia wniosku o otwarcie postępowania sanacyjnego zarówno dłużnika jak i jego wierzycieli osobistych ${ }^{8}$.

Znaczenie, jakie ustawodawca przypisuje oddzieleniu postępowania obejmującego likwidację przedsiębiorstwa dłużnika od procedur służących jego reorganizacji i naprawy sytuacji ekonomicznej najtrafniej oddaje przytoczony poniżej fragment uzasadnienia do projektu ustawy Prawo restrukturyzacyjne: „Dla możliwości przeprowadzenia skutecznej restrukturyzacji przedsiębiorstwa istotne znaczenie ma społeczny odbiór określonej regulacji prawnej i postępowania, w którym restrukturyzacja ma nastąpić. Praktyka pokazuje, że wielokrotnie sam fakt ogłoszenia upadłości dłużnika wyklucza wszelką możliwość skutecznej restrukturyzacji, niezależnie od tego czy jest to upadłość z możliwością zawarcia układu czy likwidacyjna. Skojarzenia upadłości z końcem działalności, bankructwem i brakiem możliwości odzyskania swoich wierzytelności są tak silne, że w wielu przypadkach, po ogłoszeniu upadłości, wierzyciele nie chcą podejmować żadnych rozmów z dłużnikiem. Z tych względów projekt zakłada oddzielenie postępowań restrukturyzacyjnych od stygmatyzujących postępowań upadłościowych. Dla jasnego i klarownego podziału zdecydowano się uregulować postępowania restrukturyzacyjne w osobnej ustawie"9.

Jak już wspomniano, wskutek postepowań restrukturyzacyjnych zachodzi przede wszystkim konwersja zobowiązań dłużnika niewypłacalnego (lub zagrożonego niewypłacalnością) ${ }^{10}$, a także, w zależności od sytuacji w jakiej się znajduje, restrukturyzacja jego majątku,

\footnotetext{
7 Zob. Zimmerman P., Prawo upadłościowe. Prawo restrukturyzacyjne. Komentarz, stan prawny na 2016 r., uwagi do art. 2 PrRestr, Legalis.

8 Zob. Zimmerman P., Prawo upadłościowe..., uwagi do art. 7 PrRestr., Legalis.

9 Patrz: uzasadnienie do projektu ustawy prawo restrukturyzacyjne dostępne na https://www.ms.gov.pl/pl/nowelizacja-prawa-upadlosciowego-i-naprawczego/download,2585,19.html, s. 7 .

10 Zgodnie z ust. 2 art. 6 PrRestr przez dłużnika niewypłacalnego należy rozumieć dłużnika niewypłacalnego w rozumieniu ustawy z dnia 28 lutego 2003 r. Prawo upadłościowe (w skrócie: PrUp), a zatem w myśl art. 11 ust. 1 PrUp dłużnik jest niewypłacalny, jeżeli utracił zdolność do wykonywania swoich wymagalnych zobowiązań pieniężnych. Ponadto, jeżeli dłużnik jest osobą prawną albo jednostką organizacyjną nieposiadającą
} 
zmiany w sposobie prowadzenia przedsiębiorstwa, czy też w zatrudnieniu ${ }^{11}$. Nie trzeba podkreślać, że zachowanie przedsiębiorstwa dłużnika oznacza utrzymanie przynajmniej części miejsc pracy przez dotychczasowych pracowników oraz, co do zasady, umożliwia nieprzerwane realizowanie umów, wywołując w ten sposób pozytywne skutki społeczno-gospodarcze.

Wpływ postępowań restrukturyzacyjnych na istnienie stosunku pracy jest zasadniczym wątkiem, który zostanie zgłębiony w dalszej części niniejszego artykułu.

\section{Wpływ postępowania o zatwierdzenie układu, przyśpieszonego postępowania układowego oraz postępowania układowego na sytuację prawną pracowników dłużnika}

Pierwszym z czterech rodzajów postępowań restrukturyzacyjnych jest postępowanie o zatwierdzenie układu, które zgodnie $\mathrm{z}$ art. 3 ust. 2 PrRestr umożliwia zawarcie układu w wyniku samodzielnego zebrania przez dłużnika głosów wierzycieli, bez udziału sądu, przy czym suma wierzytelności spornych uprawniających do głosownia nad układem nie może przekraczać 15\% sumy wierzytelności uprawniających do głosowania nad układem. Jak wskazuje P. Zimmerman, wprowadzenie takiego rozwiązania stanowi odstąpienie od przyjętej na gruncie poprzedniej ustawy zasady zawierania układu przez wierzycieli, bez konieczności uzyskania zgody dłużnika, gdyż tutaj to inicjatywna dłużnika ma znaczenie pierwszorzędne ${ }^{12}$. Natomiast przyśpieszone postępowanie układowe, zostało uregulowane w ust. 3 art. 3 PrRestr., który wskazuje, że możliwe jest zawarcie przez dłużnika układu po sporządzeniu i zatwierdzeniu spisu wierzytelności w uproszczonym trybie, jeżeli suma wierzytelności spornych uprawniających do głosowania nad układem nie przekracza 15\% sumy wierzytelności uprawniających do głosowania nad układem. Z kolei postępowanie układowe, o którym mowa w ust. 4 omawianego przepisu umożliwia dłużnikowi zawarcie

osobowości prawnej, której odrębna ustawa przyznaje zdolność prawną jest on niewypłacalny również wtedy, gdy jego zobowiązania pieniężne przekraczają wartość jego majątku, a stan ten utrzymuje się przez okres przekraczający 24 miesiące - art. 11 ust. 3 PrUp. Z kolei pojęcie zagrożenia niewypłacalnością występuje jedynie na gruncie postępowań restrukturyzacyjnych i oznacza, że dłużnik pozostaje w sytuacji ekonomicznej wskazującej na to, że w niedługim czasie może stać się niewypłacalny.

11 Zob. Gurgul S., Prawo upadłościowe. Prawo restrukturyzacyjne. Komentarz, stan prawny na 2016 r., uwagi do art. 2 PrRestr, Legalis.

12 Zob Zimmerman P., Prawo upadłościowe..., uwagi do art. 1 PrRestr, Legalis. 
układu po sporządzeniu i zatwierdzeniu spisu wierzytelności, pod warunkiem, że suma wierzytelności spornych uprawniających do głosowania nad układem przekracza $15 \%$ sumy wierzytelności uprawniających do głosowania nad układem.

Należy w tym miejscu podkreślić dwie istotne kwestie. Po pierwsze to, które z wymienionych rodzajów postępowań znajdzie zastosowanie, zależy nie tylko od tego, czy w danej sytuacji zostały spełnione szczegółowe przesłanki wskazane w art. 3 ust. 2-4 PrRestr., ale także od woli dłużnika. Zgodnie z art. 7 ust. 1 PrRestr. postępowanie restrukturyzacyjne wszczyna się na wniosek restrukturyzacyjny złożony przez dłużnika, chyba że ustawa stanowi inaczej. Z przepisu tego wynika, że sąd restrukturyzacyjny nie może wszcząć postępowania restrukturyzacyjnego innego niż to wskazane przez dłużnika w złożonym przez niego wniosku, a co za tym idzie, jeżeli okaże się, że dłużnik złożył wniosek o otwarcie danego rodzaju postepowania bez spełnienia ustawowo określonych przesłanek, sąd będzie zmuszony do oddalenia takiego wniosku, nie ma on bowiem prawa do samodzielnego dostosowania trybu postępowania restrukturyzacyjnego do okoliczności danej sprawy ${ }^{13}$. Po drugie, zaakcentowania wymaga istnienie zasady pierwszeństwa postępowań restrukturyzacyjnych, która oznacza, że w sytuacji, w której dojdzie do jednoczesnego złożenia wniosku restrukturyzacyjnego oraz wniosku o ogłoszenie upadłości, w pierwszej kolejności sąd rozpoznaje wniosek restrukturyzacyjny (art. 11 PrRestr.). W razie wpłynięcia wniosku o wszczęcie postępowania restrukturyzacyjnego, zgodnie $\mathrm{z}$ art. 12 ust. 1 i ust. 2 PrRestr., sąd restrukturyzacyjny niezwłocznie po powzięciu wiadomości o złożeniu wniosku o ogłoszenie upadłości zawiadamia o tym sąd upadłościowy, który wstrzymuje rozpoznanie wniosku o ogłoszenie upadłości do czasu prawomocnego orzeczenia w sprawie wniosku restrukturyzacyjnego, z wyjątkiem sytuacji przewidzianych w ust. 3 i ust. $4^{14}$.

\footnotetext{
13 Zob. Adamus R., Prawo restrukturyzacyjne..., uwagi do art. 3 PrRestr., Legalis 14 Zgodnie z art. 12 ust. 3 PrRestr. nie wstrzymuje się rozpoznania wniosku o otwarcie postępowania upadłościowego, jeżeli zagrażałoby to interesowi ogółu wierzycieli. Sąd upadłościowy wydaje wtedy postanowienie o przejęciu wniosku restrukturyzacyjnego do wspólnego rozpoznania z wnioskiem o ogłoszenie upadłości i rozstrzyga tę kwestię jednym postanowieniem. Z kolei ust. 4 art. 12 PrRestr. przewiduje wyjątek, kiedy to sąd upadłościowy nie przejmuje wniosku restrukturyzacyjnego, ale od razu przechodzi do rozpoznania wniosku o ogłoszenie upadłości. Ma to miejsce w sytuacji, gdy przejęcie wniosku restrukturyzacyjnego do wspólnego rozpoznania z wnioskiem o ogłoszenie upadłości prowadziłoby do znacznego opóźnienia wydania orzeczenia w przedmiocie ogłoszenia upadłości, ze szkodą dla wierzycieli, zaś podstawy postępowania restrukturyzacyjnego przedstawione przez dłużnika są znane sądowi upadłościowemu.
} 
Wszystkie z omówionych powyżej rodzajów postępowań restrukturyzacyjnych odnoszą takie same skutki względem pracowników zatrudnionych u dłużnika, który poddał się procedurom restrukturyzacyjnym. Zasadnicze różnice powstają w trybie postępowania sanacyjnego, dlatego też problem ten zostanie przeanalizowany odrębnie. Podstawową regulacją dotyczącą wpływu postępowań restrukturyzacyjnych na zobowiązania wynikające ze stosunku pracy jest art. 163 ust. 1 PrRestr. Przepis ten chroni wynagrodzenie pracownika, przy czym chodzi tutaj o minimalne wynagrodzenie za pracę, o którym mowa w ustawie z dnia 10 października 2002 r. o minimalnym wynagrodzeniu za pracę (tekst jedn. Dz. U. z 2015 r., poz. 2008) oraz w Rozporządzeniu Rady Ministrów ${ }^{15}$. Zgodnie z art. 163 ust 1 PrRestr. warunki restrukturyzacji zobowiązań ze stosunku pracy nie mogą pozbawiać pracowników minimalnego wynagrodzenia za pracę. Jak wskazuje P. Zimmerman „wierzytelności pracownicze, jako uprzywilejowane $\mathrm{w}$ postępowaniu upadłościowym, a $\mathrm{w}$ ramach restrukturyzacji objęte układem tylko za zgodą pracownika, z natury rzeczy objęte będą korzystniejszymi warunkami restrukturyzacji niż inne wierzytelności"16. Wynika to również z przypisywanego minimalnemu wynagrodzeniu za pracę istotnego znaczenia społecznego i ekonomicznego. Do wierzytelności ze stosunku pracy, które za zgodą pracowników zostają objęte układem, oprócz wynagrodzenia za pracę, zaliczyć można między innymi należności za niewykorzystany urlop, czy z tytułu czasowej niezdolności do pracy.

Jak wspomniano powyżej, objęcie wierzytelności pracowniczych układem może nastąpić jedynie za zgodą pracownika, o czym mowa w art. 151 ust. 2 Pr Restr. W przeciwnym razie wierzytelności te są wyłączone z układu. Zgoda pracownika musi być wyrażona w sposób bezwarunkowy i nieodwołalny, najpóźniej przed przystąpieniem do głosowania nad układem i może zostać złożona ustnie do protokołu na zgromadzeniu wierzycieli. Pracownik nie może jednak wyrazić zgody w ten sposób, że w ramach postępowania restrukturyzacyjnego, zrzeknie się części albo całości minimalnego wynagrodzenia za pracę. Artykuł 163 ust. 1 PrRestr. stanowi lex specialis w stosunku do art. 84 Kodeksu pracy ${ }^{17}$, który zawiera ogólny zakaz zrzeczenia się prawa do wynagrodzenia oraz przenoszenia tego prawa na inną osobę, ponieważ

\footnotetext{
15 Zob. Gurgul S., Prawo upadłościowe. Prawo restrukturyzacyjne..., uwagi do art. 163 PrRestr., Legalis.

16 Zob. Zimmerman P., Prawo restrukturyzacyjne..., uwagi do art. 163 PrRestr., Legalis.

17 Ustawa z dnia 26 czerwca 1974 r. Kodeks pracy, tekst jedn. Dz. U. z 2014 r., poz. 1502, w skrócie: k.p.
} 
powołany przepis Prawa restrukturyzacyjnego zezwala na rezygnację przez pracownika z części wynagrodzenia wykraczającej ponad kwotę minimalnego wynagrodzenia ${ }^{18}$.

W myśl art. 161 ust. 1 PrRestr. propozycje układowe mogą przewidywać podział wierzycieli na grupy obejmujące poszczególne kategorie interesów. Zgodnie z pkt 1 wskazanego przepisu, jedną z tych grup są wierzyciele, którym przysługują wierzytelności ze stosunku pracy a którzy wyrazili zgodę na objęcie tych wierzytelności układem. Podział wierzycieli na poszczególne grupy zdaje się czymś naturalnym, gdyż przysługujące im wierzytelności mają swoje źródło w różnych stosunkach prawnych, a w związku z tym wierzyciele są w różnym stopniu zainteresowani układem ${ }^{19}$. Oczywiste jest, że jeden wierzyciel może zostać ujęty na kilku listach wierzytelności np. pracownik, który posiada względem dłużnika - pracodawcy również wierzytelność wynikającą ze stosunku cywilnoprawnego zalicza się zarówno do pierwszej grupy wierzycieli, jak i do grupy związanej z tym stosunkiem prawnym ${ }^{20}$. Podział wierzycieli na poszczególne kategorie w znacznej mierze ułatwia zawarcie układu, pozwala to bowiem na przygotowanie odrębnych propozycji układowych dla każdej z grup oraz usprawnia proces głosowania nad układem, zwiększając szanse na jego przyjęcie ${ }^{21}$. Kwestię uchwały o przyjęciu układu reguluje art. 119 PrRestr., zgodnie z którym uchwała ta zapada, jeżeli wypowie się za nią większość wierzycieli tworzących zgromadzenie wierzycieli, mających co najmniej dwie trzecie sumy wierzytelności przysługujących głosującym wierzycielom a ich głosy były ważne (ust. 1). Natomiast, jeżeli głosowanie nad układem przeprowadza się w grupach wierzycieli, które obejmują poszczególne kategorie interesów wierzycieli, układ będzie przyjęty, gdy opowie się za nim większość wierzycieli głosujących $\mathrm{w}$ danej grupie, mających łącznie co najmniej dwie trzecie sumy wierzytelności przysługujących głosującym wierzycielom z tej grupy (ust. 2). Gdy układ nie uzyskał wymaganej większości w niektórych grupach wierzycieli, zaś wierzyciele mający łącznie dwie trzecie sumy wierzytelności przysługujących wierzycielom głosowali za układem, układ zostanie przyjęty, jeżeli wierzyciele z grup opowiadających się przeciwko układowi zostaną na podstawie układu zaspokojeni w stopniu nie mniej korzystnym niż w przypadku przeprowadzenia postępowania upadłościowego (ust. 3). Z opisanej regulacji wynika, że dokonanie podziału wierzycieli na grupy

\footnotetext{
18 Zob. Adamus R., Prawo restrukturyzacyjne..., uwagi do art. 163 PrRestr., Legalis.

19 Zob. Adamus R., Prawo restrukturyzacyjne..., uwagi do art. 161 PrRestr., Legalis.

20 Zob. Zimmerman P., Prawo restrukturyzacyjne..., uwagi do art. 161 PrRestr., Legalis.

21 Zob. Adamus R., Prawo restrukturyzacyjne..., uwagi do art. 161 PrRestr., Legalis.
} 
obejmujące poszczególne kategorie interesów ma sens zwłaszcza przy dużej różnorodności przysługujących względem dłużnika wierzytelności, i chociaż pracownicy, którzy wyrazili zgodę na objęcie ich układem, nie będą stanowili „silnej grupy” biorąc pod uwagę udział przysługujących im wierzytelności w stosunku do sumy wierzytelności przysługujących wszystkim wierzycielom, to $\mathrm{w}$ wyniku dokonania podziału na grupy wierzycieli znajdą się oni w znacznie korzystniejszej sytuacji ${ }^{22}$.

$\mathrm{Na}$ marginesie należy wspomnieć, że przepisy dotyczące wierzytelności ze stosunku pracy stosuje się odpowiednio do wierzytelności Funduszu Gwarantowanych Świadczeń Pracowników o zwrot świadczeń wypłaconych pracownikom dłużnika (art. 153 PrRestr). Fundusz, w chwili dokonania wypłaty świadczeń na rzecz pracowników, wstępuje w prawa zaspokojonego wierzyciela na podstawie art. 518 Kodeksu cywilnego ${ }^{23}$. Zatem, jeżeli Fundusz wyrazi zgodę na objęcie jego wierzytelności układem, staje się uczestnikiem postępowania restrukturyzacyjnego, natomiast restrukturyzacja jego wierzytelności może polegać jedynie na odroczeniu terminu płatności lub rozłożeniu na raty zobowiązań z tytułu wypłat dokonanych na rzecz pracowników, chyba że dysponent Funduszu wyrazi zgodę na inny sposób restrukturyzacji (art. 160 ust. 4 w zw. z art. 156 ust. 3 pkt 2 PrRestr) ${ }^{24}$.

Podsumowując, wszczęcie postępowań restrukturyzacyjnych oddziałuje na sytuację prawną pracowników dłużnika o tyle, o ile wyrazili oni zgodę na objęcie układem przysługujących im wierzytelności ze stosunku pracy (art. 161 ust. 1 pkt 1 PrRestr.). Przepisy ustawy Prawo restrukturyzacyjne chronią przede wszystkim wynagrodzenie za pracę, przy czym chodzi tutaj o minimalne wynagrodzenie za pracę (art. 163 PrRestr.)-pracownicy nie mogą bowiem wyrazić zgody na zredukowanie ich wynagrodzenia poniżej kwoty minimalnego wynagrodzenia. Ponadto, wierzyciele, którym przysługują wierzytelności ze stosunku pracy mogą tworzyć grupę wierzycieli wyodrębnioną ze względu na łączącą ich kategorię interesów, jednak z uwagi na łączną sumę przysługujących pracownikom wierzytelności, zazwyczaj nie będą oni mieli realnego wpływu na zawarcie układu.

\footnotetext{
22 Zob. Adamus R., Prawo restrukturyzacyjne..., uwagi do art. 161 PrRestr., Legalis.

23 ustawa z dnia 23 kwietnia 1964 r. Kodeks cywilny, tekst jedn. Dz. U. z 2014 r., poz. 121 z późn. zm., w skrócie: k.c.

${ }^{24}$ Zob. Zimmerman P., Prawo restrukturyzacyjne..., uwagi do art. 153 PrRestr., Legalis.
} 


\section{Wpływ postępowania sanacyjnego na sytuację prawną pracowników dłużnika}

$\mathrm{Z}$ uwagi na to, że postępowanie sanacyjne rodzi dalej idące konsekwencje w stosunku do sytuacji prawnej pracowników dłużnika, niż postępowania przedstawione w poprzedniej części opracowania, zachodzi konieczność jego odrębnego omówienia. Wskazane do tej pory przepisy są przepisami ogólnymi o postępowaniach restrukturyzacyjnych i ich skutkach, stąd będą one miały zastosowanie do wszystkich jego rodzajów, w tym do postępowania sanacyjnego. Postępowanie sanacyjne zostało uregulowane w art. 3 ust. 5 PrRestr., zgodnie z którym umożliwia ono dłużnikowi przeprowadzenie działań sanacyjnych oraz zawarcie układu po sporządzeniu i zatwierdzeniu spisu wierzytelności. Skutki postępowania sanacyjnego mogą polegać przede wszystkim na zawieszeniu egzekucji prowadzonej z majątku wchodzącego do masy sanacyjnej i uchyleniu dokonanych zajęć, niedopuszczalności skierowania egzekucji do majątku wchodzącego w skład masy sanacyjnej, możliwości prowadzenia postępowań sądowych i administracyjnych jedynie przez zarządcę, zakazie wypowiadania umów najmu lub dzierżawy lokalu lub nieruchomości, w których dłużnik prowadzi przedsiębiorstwo, umów leasingu, ubezpieczeń majątkowych, rachunku bankowego, kredytu, pożyczki, poręczeń, gwarancji bankowych, akredytyw oraz licencji udzielonych dłużnikowi, zakazie obciążania majątku w celu zabezpieczenia wierzytelności powstałej przed otwarciem postępowania, wygaśnięciu prokury i pełnomocnictw ${ }^{25}$. Jest to postępowanie odpowiednie dla dłużnika, który znajduje się w sytuacji ekonomicznej wywołującej potrzebę gruntownej restrukturyzacji, ponieważ jednocześnie może on podjąć działania sanacyjne, mianem których ustawodawca określa czynności prawne i faktyczne, które zmierzają do poprawy sytuacji ekonomicznej dłużnika i mają na celu przywrócenie mu zdolności do wykonywania zobowiązań, przy jednoczesnej ochronie przed egzekucją. Działania te polegać będą przede wszystkim na możliwości odstąpienia od niekorzystnych umów, zbyciu zbędnego, generującego koszty majątku, zwolnieniu nieefektywnych i zbędnych pracowników, odwróceniu skutków czynności zdziałanych na szkodę wierzycieli 26 .

Odnosząc się do kwestii możliwości zwolnienia nieefektywnych i zbędnych pracowników, należy przytoczyć treść art. 300 PrRestr.,

\footnotetext{
25 Tak: Gurgul S., Prawo upadłościowe. Prawo restrukturyzacyjne..., uwagi do art. 3 PrRestr., Legalis.

26 Tak: Zimmerman P., Prawo restrukturyzacyjne..., uwagi do art. 3 PrRestr., Legalis.
} 
w myśl którego otwarcie postępowania sanacyjnego wpływa na stosunki pracy i wywołuje w zakresie praw i obowiązków pracownika i pracodawcy takie same skutki, jak ogłoszenie upadłości, przy czym uprawnienia syndyka wykonuje zarządca. Regulacje dotyczące wpływu postępowania upadłościowego na stosunki pracy znajdują się w Kodeksie pracy.

Zdaniem P. Zimmermana reorganizacja zatrudnienia jest najistotniejszym elementem skutecznej restrukturyzacji. Na pierwszy rzut oka może się wydawać, że postępowanie sanacyjne nie wpływa korzystnie na sytuację prawną pracowników dłużnika, który zdecydował się złożyć wniosek o wszczęcie tego rodzaju postępowania, jednak należy mieć na uwadze, że w poprzednim stanie prawnym, wobec dłużnika znajdującego się w złej sytuacji ekonomicznej zostałoby wszczęte postępowanie upadłościowe obejmujące likwidację majątku upadłego, a w konsekwencji doszłoby do rozwiązania stosunku pracy ze wszystkimi pracownikami. Natomiast omawiany rodzaj postępowania restrukturyzacyjnego pozwala na przynajmniej częściowe zachowanie dotychczasowych miejsc pracy27.

Wprawdzie, zgodnie $\mathrm{z}$ art. $41^{1} \S 1$ k.p. w razie ogłoszenia upadłości pracodawcy nie stosuje się ogólnych przepisów prawa pracy dotyczących ochrony stosunku pracy ani przepisów szczególnych dotyczących ochrony pracowników przed wypowiedzeniem, czy rozwiązaniem umowy o pracę, to jednak w postępowaniu sanacyjnym istnieją pewne mechanizmy korzystnie wpływające na sytuację pracowników dłużnika, takie jak: obowiązek zamieszczenia w planie restrukturyzacyjnym informacji o zasadach zwalniania pracowników, które wraz z planem wymagają zatwierdzenia przez sędziego - komisarza, uprawnienie sędziego - komisarza do uniemożliwienia zarządcy zwalniania określonej grupy pracowników lub do ograniczenia ilości zwalnianych pracowników. Zatem, sędzia - komisarz posiada instrumenty pozwalające mu na kontrolowanie działań zarządcy względem pracowników ${ }^{28}$. Na marginesie, problematyka obowiązków zarządcy wobec pracowników została szczegółowo unormowana w ustawie z dnia 13 lipca 2006 r. o ochronie roszczeń pracowniczych w razie niewypłacalności pracodawcy ${ }^{29}$ (tekst jedn. Dz.U. z 2014 r. poz. 272 z późn. zm.).

\footnotetext{
${ }^{27}$ Zob. Zimmerman P., Prawo restrukturyzacyjne..., uwagi do art. 3 PrRestr., Legalis.

28 Ibidem.

${ }^{29}$ Zob. Gurgul S., Prawo upadłościowe. Prawo restrukturyzacyjne..., uwagi do art. 300 PrRestr., Legalis.
} 
Przepisy Kodeksu pracy opisujące działania, które mogą zostać podjęte względem pracowników dłużnika w razie ogłoszenia jego upadłości, a które na mocy art. 300 PrRestr. stosuje się odpowiednio w razie wszczęcia postępowania sanacyjnego, uprawniają zarządcę do podjęcia następujących kroków: skrócenia czasu wypowiedzenia umowy na czas nieokreślony (art. $36^{1}$ k.p.) ${ }^{30}$, wypowiedzenia umowy o pracę zawartej na czas nieokreślony bez konieczności konsultacji z zakładową organizacją związkową reprezentującą pracownika (art. $38 \S 1 \mathrm{w}$ zw. z art. $41^{1} \S 1$ k.p.), wypowiedzenia umowy o pracę pracownikowi, któremu brakuje nie mniej niż 4 lata do osiągnięcia wieku emerytalnego (art. 39 w zw. z art. $41^{1} \S 1$ k.p.), wypowiedzenia umowy o pracę w czasie urlopu pracownika oraz innej usprawiedliwionej nieobecności (art. 41 w zw. z art. $41^{1} \S 1$ k.p.), wypowiedzenia albo rozwiązania umowy o pracę z pracownicą $\mathrm{w}$ okresie ciąży lub urlopu macierzyńskiego, jak również z pracownikiem - ojcem wychowującym dziecko w okresie korzystania z urlopu macierzyńskiego (art. 177 § 4 oraz $\S 5$ k.p.), wypowiedzenia albo rozwiązania umowy o pracę w okresie od dnia złożenia przez pracownika wniosku o udzielenie urlopu wychowawczego do dnia zakończenia tego urlopu, jak również od dnia złożenia przez pracownika uprawnionego do urlopu wychowawczego wniosku o obniżenie wymiaru czasu pracy do dnia powrotu do nieobniżonego wymiaru czasu pracy (art. $186^{8} \S 1$ k.p.), rozwiązania za wypowiedzeniem umowy o pracę zawartej w celu przygotowania zawodowego (art. 196 pkt 2 k.p.), dokonania zwolnień grupowych, zgodnie z ustawą z dnia 13 marca 2003 r. o szczególnych zasadach rozwiazywania z pracownikami stosunków pracy z przyczyn niedotyczących pracowników (tekst jedn. Dz. U. z 2015 r., poz. 192) ${ }^{31}$.

Sytuacja prawna pracowników w postępowaniu sanacyjnym jest bardziej złożona niż w pozostałych rodzajach postępowań restrukturyzacyjnych. Chociaż wydawać by się mogło, że jest ono mniej korzystne dla pracowników, ponieważ wyłącza stosowanie wielu regulacji Kodeksu pracy mających na celu ochronę stosunku pracy, to jednak ze względu na cel, który przyświeca postępowaniu sanacyjnemu, a którym jest zachowanie przedsiębiorstwa dłużnika, pozwala ono na zachowanie przynajmniej części miejsc pracy, co nie jest możliwe w przypadku ogłoszenia upadłości.

\footnotetext{
30 od 22 lutego 2016 r. także umów o pracę na czas określony. Za czas, o który został skrócony okres wypowiedzenia przysługuje pracownikowi odszkodowanie w wysokości odpowiadającej wynagrodzeniu za ten okres.

31 Zob. Adamus R., Prawo restrukturyzacyjne..., uwagi do art. 300 PrRestr., Legalis.
} 
Na koniec, odnosząc się po krótce do ogółu zmian dokonanych nowelizacją, która weszła w życie z dniem 1 stycznia 2016 r., należy stwierdzić przede wszystkim, że jest to ustawa o znacznie większym stopniu skomplikowania niż obowiązujące wcześniej Prawo upadłościowe i naprawcze. Największą wadą Prawa restrukturyzacyjnego jest brak przejrzystości, tj. rozrzucenie przepisów dotyczących danej instytucji w wielu miejscach ustawy. Ponadto, charakteryzuje ją nadmierny rozrost materiału normatywnego oraz niejasna terminologia. Wszystko to sprawia, że stosowanie przepisów ustawy Prawo restrukturyzacyjne może rodzić wiele problemów w praktyce. 